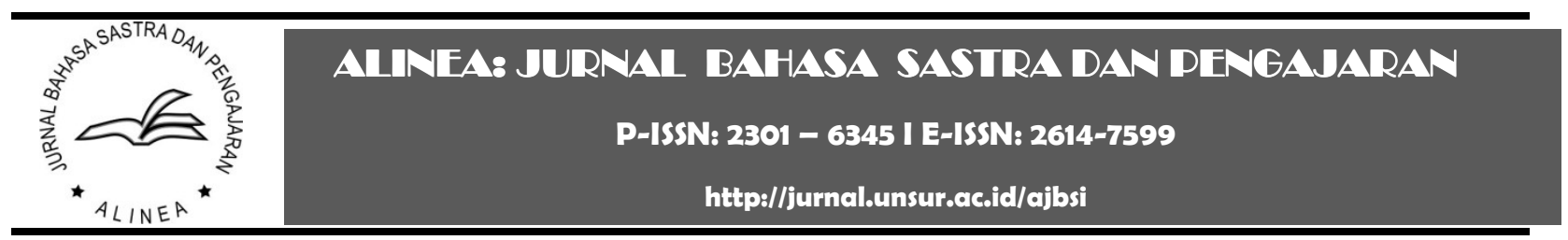

\title{
PERGESERAN PENGGUNAAN BAHASA JAWA PADA SISWA TK DAN KB DI KELURAHAN BEDURI PONOROGO
}

\author{
Rizki Mustikasari, Cutiana Windri Astuti \\ STKIP PGRI Ponorogo, Indonesia
}

Riwayat artikel:

Dikirim: 15 Februari 2020

Direvisi: 3 Maret 2020

Diterima: 8 Maret 2020

Diterbitkan: 30 April 2020

Katakunci:

bahasa Jawa

bahasa daerah

pergeseran bahasa

Alamat surat

cutiana84@gmail.com

\begin{abstract}
Abstrak:
Artikel ini akan mengungkap faktor-faktor yang mempengaruhi penuruan penggunaan bahasa Jawa di kalangan siswa Taman Kanak-kanak dan Kelompok Bermain di Kelurahan Beduri Kecamatan Ponorogo Kabupaten Ponorogo. Data dalam artikel diperoleh dari hasil observasi yang kemudian dianalisis menggunakan analisis jalur atau path analysis. Variabel endogen dalam artikel adalah pergeseran penggunaan bahasa Jawa. Variabel multibahasa keluarga sebagai variabel moderat. Adapun variabel sekolah, status sosial ekonomi keluarga, dan migrasi sebagai variabel eksogen (independent). Hasil penelitian menunjukkan (1) sekolah, status sosial ekonomi, migrasi, dan multibahasa keluarga memiliki pengaruh langsung yang berarti terhadap pergeseran penggunaan bahasa Jawa; (2) ada pengaruh tidak langsung yang berarti dari sekolah, status sosial ekonomi, migrasi, dan multi bahasa keluarga terhadap pergeseran penggunaan bahasa Jawa; (3) sekolah, status sosial ekonomi, migrasi, dan multibahasa keluarga memiliki pengaruh total yang berarti terhadap pergeseran penggunaan bahasa Jawa.
\end{abstract}

\begin{abstract}
:
This article will reveal factors that influence the decline in the use of Javanese language among Kindergarten and Play Group students in Beduri Village, Ponorogo District, Ponorogo Regency. The data in the article were obtained from observations which were then analyzed using path analysis. An endogenous variable in the article is a shift in the use of Javanese. Family multilingual variables as moderate variables. Meanwhile, the school, family socioeconomic status, and migration variables as exogenous (independent) variables. The results show that (1) school, socioeconomic status, migration, and family multilingual have a significant direct effect on the shift of Javanese language use; (2) there is a significant indirect effect from school, socioeconomic status, migration, and multi-language family on the shift of Javanese language use; (3) school, socioeconomic status, migration, and family multilingual have a significant total influence on the shift of Javanese language use.
\end{abstract}

\section{PENDAHULUAN}

Indonesia adalah negara yang memiliki beragam suku bangsa. Berdasarkan hasil sensus BPS tahun 2010 ada 1.340 suku dan 742 bahasa daerah. Akan tetapi, pada tahun 2017 jumlah bahasa daerah menyusut menjadi 652 bahasa daerah. Dewasa ini terdapat banyak bahasa daerah yang jumlah penuturnya sedikit dan sedang berada di ambang kepunahan (Henry T.), bahkan 90 bahasa daerah dinyatakan sudah punah atau tidak digunakan lagi oleh masyarakat penuturnya. Kepunahan bahasa daerah ini merupakan akibat dari pergeseran bahasa dan pergeseran penggunaan bahasa pada lingkungan masyarakat penuturnya. Dalam sebuah artikel dijelaskan bahwa penggunaan bahasa daerah oleh anak-anak dinilai kurang (Sahril).

Suku Jawa adalah suku dengan jumlah populasi terbesar di Indonesia. Jumlahnya mencapai $41 \%$ dari total populasi Indonesia. Suku Jawa memiliki bahasa daerah yaitu 
bahasa Jawa yang masih digunakan hingga saat ini. Selain berfungsi sebagai sarana komunikasi bagi masyarakat penuturnya, bahasa Jawa juga merupakan sarana pendidikan budi pekerti, sopan santun, dan unggah ungguh terhadap orang yang lebih tua atau lebih dihormati. Sayangnya penggunaan bahasa Jawa mulai mengalami pergeseran. Banyak keluarga dari suku Jawa lebih memilih menggunakan bahasa Indonesia sebagai bahasa ibu bagi anak-anak mereka. Alasannya sangat beragam, ada yang mengatakan bahwa bahasa Jawa terlalu rumit untuk digunakan karena harus menggunakan cara berbicara yang berbeda untuk kalangan orang yang berbeda pula. Ada juga yang merasa bahasa nasional lebih bermanfaat daripada bahasa daerah, karena dapat digunakan untuk berkomunikasi dengan lebih banyak orang dibandingkan dengan bahasa daerah.

Mujid dan Suyanto dalam artikelnya mengatakan bahwa masyarakat sekarang, khususnya yang sudah menikah, sebagian besar menggunakan kombinasi antara bahasa ibu dan bahasa Indonesia, walaupun berasal dari bahasa ibu yang sama. Pendapat tersebut dapat dianalogikan pada masyarakat dengan bahasa ibu bahasa Jawa (Mujid and Suyanto).

Penggunaan bahasa nasional yaitu bahasa Indonesia sebagai bahasa ibu, menyebabkan anak-anak pada tingkat Taman KanakKanak dan Kelompok Bermain mengalami pergeseran penggunaan bahasa Jawa. Hal tersebut memunculkan kekhawatiran akan punahnya bahasa Jawa sebagai bahasa daerah di Indonesia. Jika bahasa daerah punah, maka identitas kedaerahannya pun akan hilang dan jika identitas hilang, bangsa ini akan sulit membangun karakter bangsa sebagai mana siungkapkan bahwa "character is fundamental and highly essential for human because it is the characteristic and identyty of human" (Adawiyah \& Munsi). Karena karakter merupakan hal yang mendasar dan penting untuk seseorang yang dapat menjadi ciri dan identitasnya, identitas itu perlu ditanamkan pada anak-anak dengan cara mewujudkan sikap postif terhadap bahasa daerah.
Menurut Aan Setyawan dalam artikelnya yang berjudul "Bahasa Daerah dalam Perspektif Kebudayaan dan Sosio-linguistik: Peran dan Pengaruhnya dalam Pergeseran dan Pemertahanan Bahasa," terjadi semacam "kebocoran diglossia dalam bebe-rapa domain keluarga yaitu dipilihnya bahasaa Indonesia sebagai bahasa utama merupakan salah satu indikasi bahwa pemakaian bahasa daerah sedang mengalami pergeseran" (A. Setyawan). Pada usia dini anak dinilai me-miliki kemampuan otak yang cukup baik dalam menyerap suatu bahasa. Pada masa tersebut otak anak sedang mengalami fase perkembangan, sehingga dapat cepat merespon berbagai stimulus yang merangsangnya, termasuk kosakata-kosakata yang dia dengar. Bahasa yang akan tersimpan kuat dalam memori seorang anak bahkan sampai dia besar nanti adalah bahasa ibu atau bahasa yang digunakan di lingkungan keluarganya. Oleh karena itu, jika pada usia dini anak tidak mengenal bahasa Jawa dengan baik, hingga dewasa dia akan kesulitan dalam menggunakan bahasa Jawa dan pada akhirnya bahasa Jawa akan mengalami kepunahan. Agar bahasa jawa tetap terjaga eksistensinya, perlu diketahui faktor-faktor penyebab pergeseran penggunaan bahasa Jawa. Utamanya penggunaan bahasa Jawa pada siswa TK dan KB sebagai generasi masyarakat penuturnya.

Artikel serupa pernah dilakukan oleh Afifah Raihany (2015) yang berjudul "Pergeseran Penggunaan Bahasa Madura di Kalangan Anak- anak Sekolah Dasar Negeri di Desa Pangarangan Kecamatan Kota Sumenep." Dalam artikelnya, Afifah menemukan bahwa kedudukan dan fungsi bahasa Madura mengalami pergeseran di kalangan anak-anak SD di desa Pangarangan kecamatan Kota Sumenep (Raihany). Temuan lain juga diungkapkan oleh Hari Bakti Mardikantoro (2007) dalam artikelnya yang berjudul "Pergeseran Bahasa Jawa dalam Ranah Keluarga pada Masyarakat Multibahasa di Wilayah Kabupaten Brebes". Dalam tulisan itu dikemukan bahwa telah terjadi pergeseran bahasa Jawa dalam ranah keluarga pada 
masyarakat multilingual di wilayah Kabupaten Brebes (Mardikantoro).

Artikel ini akan memaparkan faktorfaktor yang mempengaruhi penuruan penggunaan bahasa Jawa di kalangan siswa taman kanak-kanak dan kelompok bermain di Kelurahan Beduri Kecamatan Ponorogo Kabupaten Ponorogo. Artikel ini diharapkan dapat (1) dapat memberikan informasi kepada peneliti dan stake holder terkait tentang factor yang menyebabkan pergeseran penggunaan bahasa Jawa di kalangan siswa taman kanakkanak dan kelompok bermain, (2) menjadi bahan pertimbangan untuk membuat kebijakan terkait penggunaan Bahasa Jawa di kalangan siswa taman kanak-kanak dan kelompok bermain, dan (3) melestarikan warisan budaya bangsa, yaitu bahasa Jawa.

\section{Pergeseran Penggunaan Bahasa Jawa}

Pergeseran bahasa merupakan hasil dari proses pemilihan bahasa dalam jangka waktu yang sangat panjang. Pergeseran Bahasa pada umumnya mengacu pada proses penggantian penggunaan suatu bahasa dengan bahasa lainnya pada seorang penutur maupun pada suatu masyarakat tutur (Ibrahim dkk.). Bahasa baru lebih dipilih oleh anggota suatu komunitas bahasa daripada bahasa lama yang secara tradisional sudah biasa digunakan (Fasolt). Senada dengan hal tersebut, Kridalaksana menyatakan pergeseran bahasa adalah perubahan secara tetap dalam pilihan bahasa seseorang untuk keperluan sehari hari terutama sebagai akibat migrasi (Kridalaksana).

Lebih singkat Imam menyatakan bahwa pergeseran bahasa mencermati peralihan suatu masyarakat menuju bahasa baru. Senada dengan pendapat sebelumnya Sulis Triyono dalam artikelnya menyatakan pergeseran bahasa yang terjadi pada hampir semua bahasa menandakan adanya dinamisasi bahasa yang digunakan masyarakat untuk berkomunikasi (Triyono). Pergeseran bahasa seperti yang telah didefinisikan oleh para tokoh tersebut dapat kita lihat dalam kehidupan sehari-hari. Hampir di segala umur penggunaan bahasa daerah terutama bahasa jawa mulai mengalami pergeseran.

Terdapat banyak faktor yang mempengaruhi pergeseran bahasa. Sumarsono dan Partana menyatakan bahwa pergeseran bahasa diakibatkan oleh sekolah (Sumarsono and Partana). Sekolah yang lebih mengajarkan bahasa nasional dan bahasa asing kepada siswanya sering dituding sebagai salah satu faktor penyebab bergesernya bahasa daerah sebagai bahasa ibu. Sedangkan Chaer menyatakan bahwa pergeseran bahasa menyangkut masalah penggunaan bahasa oleh seorang penutur atau sekelompok penutur yang biasa disebabkan oleh perpindahan antar masyarakat tutur (Chaer). Ilham Setyawan menyatakan bahwa berpindahnya orang-orang kota ke wilayah pedesaan serta banyak dibangunnya perumahan di dekat atau di daerah pedesaan sehingga banyak pendatang yang latar belakangnya bukan orang Jawa juga berpengaruh terhadap menurunnnya intensitas pemakaian Bahasa Jawa (I. Setyawan). Singkatnya, pergeseran budaya merupakan efek samping yang ditimbulkan oleh proses migrasi seorang penutur.

Nini dan Usman dalam dalam artikelnya mengatakan bahwa faktor-faktor penyebab terjadinya pergeseran Bahasa ada tiga, yaitu faktor migrasi, faktor social dan ekonomi (Nini and Usman). Posisi sebuah bahasa akan meningkat menjadi bahasa yang bernilai ekonomi tinggi yang merupakan akibat dari kemajuan ekonomi. Demikian juga dengan faktor multi bahasa. Penggunaan berbagai macam bahasa secara terus menerus akan mengakibatkan penutur bahasa daerah semakin lama semakin berkurang.

\section{Multibahasa Keluarga}

Multibahasa atau multilingual dalam masyarakat dapat memberikan dampak terhadap perkembangan bahasa yang digunakan dalam masyarakat yang bersangkutan (Pratiwi). Dampak-dampak yang muncul antara lain terjadi interferensi, integrase, perubahan bahasa (Language change), perge- 
seran bahasa (language shift). Dalam Kamus Besar Bahasa Indonesia, multibahasa diartikan sebagai kemampuan menggunakan beberapa bahasa dalam berkomunikasi. Kata beberapa menunjukkan jumlah yang lebih dari dua.

Dalam masyarakat modern saat ini, banyak keluarga yang menggunakan lebih dari dua bahasa dalam berkomunikasi sehari-hari. Hal tersebut dilakukan demi memenuhi tuntutan jaman. Kemajuan teknologi yang berasal dari luarnegeri memaksa masyarakat untuk memahami bahasa internasional yaitu bahasa Inggris. Di samping itu bahasa Indonesia yang digunakan sebagai pengantar dalam pembelajaran di sekolah mau tidak mau juga harus dikuasai. Sedangkan bahasa daerah juga masih tetap harus diperthankan dalam penggunaannya. Penggunaan multibahasa dalam sebuah keluarga sama artinya dengan menerapkan multibahasa sebagai bahasa ibu bagi seorang anak dalam keluarga tersebut. Penggunaan multibahasa sebagai bahasa ibu dapat menyebabkan pergeseran penggunaan bahasa jawa pada anak.

\section{Status Sosial Ekonomi Keluarga}

Macionis (1994:150) mengatakan bahwa "Every society is marked by inequality, with some people having more money, housing, education, health, and power than others" (Macionis). Setiap masyarakat ditandai berdasarkan ketidaksetaraan, dengan beberapa orang yang memiliki lebih banyak uang, perumahan, pendidikan, kesehatan, dan kekuasaan daripada yang lain. Menurut Slavin (2006:134), "Pakar sosiologi menilai kelas sosial, dan status ekonomi (SSE), dari segi penghasilan, pekerjaan, pendidikan, dan gengsi seseorang dalam masyarakat'(Slavin). Karena gengsi seseorag sulit untuk diukur secara empiris, maka SSE paling sering diukur sebagai kombinasi dari tingkat pendidikan, pekerjaan, dan penghasilan. Tingkat pendidikan biasanya dilihat dari pendidikan formal yang pernah ditempuh. Di Indonesia jenjang pendidikan formal yang ditempuh oleh masyarakat pada umumnya adalah SD, SMP,
SMA atau SMK, Diploma, S1, S2, dan S3. Meskipun masih ada yang tidak lulus SD.

Macionis (1994:168) membagi kelas ekonomi masyarakat ke dalam empat peringkat umum berdasarkan penghasilan, yaitu: kelas atas $(>\$ 100,000)$, kelas menengah $(\$ 50,000-\$ 100,000)$, kelas bekerja $(\$ 15,000-$ $\$ 30,000)$, dan kelas rendah $(<\$ 15,000$ atau tidak tentu). Sedangkan untuk tingkatan sosial, (Macionis) memberikan skor berdasarkan jenis pekerjaan yang dilakukan seseorang. Nilai paling tinggi untuk pekerjaan yang membutuhkan kemampuan tinggi, pendidikan tinggi, dan latihan. Rentang skor berkisar dari 09 yaitu tukang semir sepatu, hingga 86 yaitu Dokter.

Model pengelompokan lain ditunjukan pada laporan artikel Connor dan Sara (2001:3) yang berjudul Social Class and Higher Education. Dalam laporan artikel tersebut kelas sosial dikelompokkan kedalam lima kelompok yang dapat dibagi kedalam dua kelompok utama, yaitu (1) kelompok kelas sosial tinggi: I, II, dan IIIn untuk pekerja profesional, menengah dan bakat nonmanual, (2) kelompok kelas sosial rendah: IIIm, IV, dan $\mathrm{V}$ untuk bakat bekerja manual, sebagian bakat, dan tidak berbakat (Helen and Dewson). Leiulfsrud Hakon (2005:7-8 ), dkk menggunakan pembagian masyarakat ke dalam tujuh kelas ekonomi berdasarkan situasi bekerja dan keadaan pasar, antara pemilik, pegawai atasan, dan pegawai bawahan, antara perusahaan dibawah sepuluh orang pegawai dan di atas sepuluh orang pegawai, serta antara pekerja manual dan nonmanual. Kelas I dan II diberi nama kelas servis, VI dan VII kelas pekerja, sedangkan III dan V adalah kelas posisi menengah (Hakon).

Status sosial ekonomi memiliki peran penting dalam berbagai sisi kehidupan manusia, termasuk dalam bidang pendidikan. Dalam bukunya Santrock ( 2009:194) mengatakan bahwa "Status sosial ekonomi merujuk pada kategorisasi orang-orang, menurut karakteristik ekonomi, pendidikan, dan pekerjaan mereka" (Santrock) 


\section{Migrasi}

Migrasi adalah perpindahan penduduk dari suatu wilayah menuju wilayah yang lain untuk menetap dalam jangka waktu yang cukup lama. Gould dan Prothero (1975:41) walaupun seseorang telah resmi pindah tempat, tetapi bila ada niat sebelumnya untuk kembali ke tempat semula, maka harus dianggap sebagai mobilitas sirkuler dan bukan migrasi (Gould and R.M. Prothero).

Secara lebih rinci, dalam sensus tahun 1971 dan tahun 1980 digunakan konsep migrasi adalah perindahan seseorang dari satu provinsi ke provinsi yang lain dalam jangka waktu enam bulan atau lebih. Elspeth Young mengatakan bahwa beberapa penulis mengusulkan agar migrasi dianggap bagian dari suatu rangkaian kesatuan yang meliputi semua jenis perpindahan penduduk mulai dari yang nglaju sampai yang berpindah tempat untuk jangka waktu yang panjang (Young).

\section{Sekolah}

Sekolah adalah lembaga yang dirancang untuk pengajaran siswa/murid di bawah pengawasan guru. Menurut Wayne sekolah adalah sistem interaksi sosial suatu organisasi keseluruhan yang terdiri atas interaksi pribadi terkait bersama dalam suatu hubungan organik (Admodiwiro).

Sedangkan berdasarkan Undang-undang Nomor: 2 tahun 1989 sekolah adalah satuan pendidikan yang berjenjang dan berkesinambungan untuk menyelenggarakan kegiatan belajar mengajar.

Sekolah juga merupakan bagian integral dari suatu masyarakat yang berhadapan dengan kondisi nyata yang terdapat dalam masyarakat pada masa sekarang. Sekolah juga merupakan lingkungan kedua tempat anakanak berlatih dan menumbuhkan kepribadiannya (Pidarta). Oleh sebab itu, lingkungan sekolah turut berpengaruh terhadap perkembangan kepribadian dan perkembangan sosial seseorang yang berujung pada penggunaan bahsa dalam interaksi sosialnya sehari-hari.

\section{Siswa TK dan KB}

Siswa taman kanak-kanak dan kelompok bermain adalah anggota masyarakat yang berusaha mengembangkan potensi diri melalui proses pembelajaran pada jalur pendidikan taman kanak-kanak dan kelompok bermain. Pada umumnya mereka berusia antara tiga hingga enam tahun. Pada usia tersebut secara psikologis anak termasuk dalam fase usia dini.

Dalam Undang-undang Sistem Pendidikan Nasional No:20 Tahun 2003 pasal 28 ayat 1 , disebutkan bahwa anak yang termasuk anak usia dini adalah anak yang masuk dalam rentang usia 0-6 tahun. Anak usia dini adalah anak yang berkisar antara usia 0-6 tahun yang memiliki pertumbuhan dan perkembangan yang luar biasa sehingga muncul berbagai keunikan pada dirinya (Muhammad). Usia dini merupakan masa perkembangan yang menentukan perkembangan masa selanjutnya. Berbagai studi yang dilakukan para ahli menyimpulkan bahwa pendidikan anak usia dini dapat memperbaiki prestasi dan meningkatkan produktivitas kerja masa dewasanya (Syamsu L.N and Sugandhi).

Maria Montesorri mengemukakan beberapa tahapan sensitive pada anak usia dini. Menurutnya anak memiliki kemampuan sendiri untuk belajar sesuai dengan tingkat kematangannya dan anak belajar dengan cara yang berbeda dengan orang dewasa. Ada saat dimana anak akan sangat peka terhadap lingkungannya, saat tersebut dinamakan Montessori sebagai Sensitive periods (Asmidayati dkk).

Ada empat periode sensitif yang dikemukakan oleh Montesorri, yaitu: Sensitive periods for order, Sensitive periods for details, Sensitive periods for using hands, Sensitive periods for movements, Sensitive periods for learning language. Lebih lanjut, sensitive periods for learning language terbagi dalam dua fase, yaitu fase sadar dan fase tak sadar. 
Pada fase tak sadar anak-anak menyerap bunyi-bunyi, kata-kata, dan tata bahasa dari lingkungannya. Anak-anak mempelajari bahasa tanpa banyak memikirkannya. Fase ini terjadi pada rentang usia tiga bulan hingga usia tiga tahun. Sedangkan pada masa usia tiga tahun sampai enam tahun, anak mempelajari bentuk- bentuk tata bahasa baru dengan penuh kesadaran. Pada masa usia ini, anak masuk dalam fase sadar dalam belajar berbahasa atau sensitive periods for learning language.

Berdasarkan pengertian yang telah dikemukakan sebelumnya, dapat disimpulkan bahwa siswa taman kanak-kanak dan kelompok bermain sedang berada pada masa sensitive periods for learning language secara sadar. Bahasa yang dipelajari dan yang digunakan pada masa ini akan mempengaruhi kemampuannya berbahasa ketika dia dewasa. Kemampuan berbahasa yang dimaksud mencakup kemampuan berbahasa Jawa secara baik dan benar.

Kerangka pikir dalam artikel ini adalah faktor multi bahasa dalam keluarga, faktor status social dan ekonomi keluarga, faktor migrasi, dan faktor sekolah dapat menyebabkan pergeseran penggunaan bahasa jawa pada siswa taman kanak-kanak dan kelompok bermain di Kelurahan Beduri Kecamatan Ponorogo Kabupaten Ponorogo seperti yang tampak pada bagan berikut:

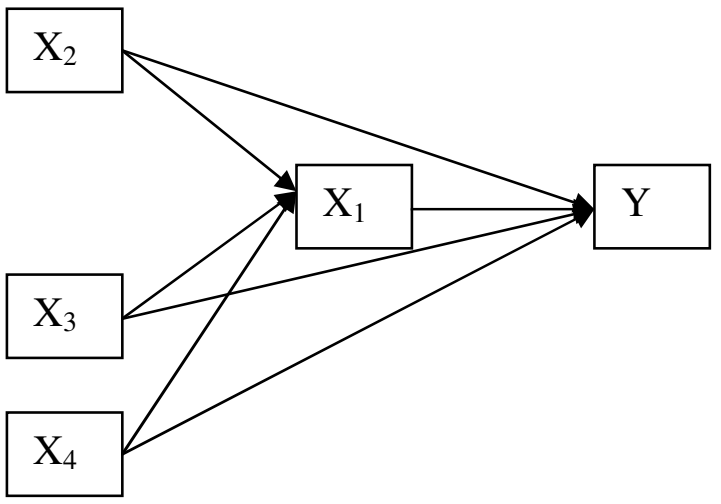

Keterangan :

$\mathrm{X}_{1} \quad$ : Multibahasa Keluarga

$\mathrm{X}_{2} \quad$ : Status Sosial dan Ekonomi Keluarga

$$
\begin{array}{ll}
\mathrm{X}_{3} & \text { : Migrasi } \\
\mathrm{X}_{4} & \text { : Sekolah } \\
\mathrm{Y} & : \text { Pergeseran Penggunaan Bahasa Jawa } \\
& \text { siswa TK dan KB }
\end{array}
$$

\section{METODE}

Pendekatan artikel ini adalah deskriptif kuantitatif. Sedangkan jenis artikel Ex Post Facto yang menggunakan metode observasi. Instrumen pengumpulan data yang digunakan berupa lembar observasi dan angket.

Populasi dalam artikel ini adalah seluruh siswa taman kanak-kanak dan kelompok bermain di Kelurahan Beduri Kecamatan Ponorogo Kabupaten Ponorogo . Sampel yang diambil adalah seluruh siswa taman Kanakkanak dan kelompok bermain di Kelurahan Beduri Kecamatan Ponorogo Kabupaten Ponorogo pada tahun pelajaran 2019/2020. Pemilihan sampel ini selain mempertimbangkan efisiensi waktu, juga mempertimbangkan keterwakilan populasi oleh sampel yang ditentukan.

Artikel ini menggunakan validitas konstruk dan validitas empiris internal. Data yang diperoleh dalam artikel dianalisis dengan metode analisis jalur (path analysis) dengan bantuan program statistik SPSS. Karena dalam artikel ini menggunakan sampel, perlu ditentukan signifikansi terhadap nilai koefisien regresi $(\beta)$ dan koefisien jalur $(\mathrm{P})$. Untuk mengetahui apakah pengaruh yang terjadi pada sampel juga terjadi pada populasi. Mengenai kriteria kebermaknaan pengaruh, peneliti menggunakan batas yang ditetapkan oleh Pedhazur (1997:806-807) yaitu >0,05 (Pedhazur).

\section{HASIL DAN PEMBAHASAN}

Berdasarkan pendahuluan dan kajian teori yang telah dikemukakan, Variabel yang diukur dalam artikel ini meliputi sekolah, status social ekonomi, migrasi, multi Bahasa keluarga, dan pergeseran penggunaan Bahasa jawa. Analisis jalur memungkinkan penulis untuk menganalisis pola hubungan antara 
variabel sehingga penulis dapat mengetahui pengaruh langsung maupun tidak langsung seperangkat variabel independen terhadap variabel dipenden. Untuk mengetahui besar pengaruh faktor sekolah, status social ekonomi keluarga, migrasi, dan multi Bahasa keluarga terhadap pergeseran penggunaan Bahasa Jawa pada siswa TK dan KB di Kelurahan Beduri kecamatan Ponorogo kabupaten Ponorogo penulis melakukan pengukuran terhadap masing masing faktor. Selain variabel pergeseran penggunaan bahasa Jawa, variabel- dalam artikel ini diukur menggunakan angket yang diisi oleh wali murid. Skor pada angket faktor sekolah ditentukan berdasarkan jumlah Bahasa pengantar yang digunakan di sekolah. Skor pada angket faktor status social ekonomi keluarga diukur berdasarkan latar belakang Pendidikan orang tua, pekerjaan orang tua, dan rata-rata pendapatan per bulan orang tua. Faktor migrasi diukur berdasarkan jarak yang ditempuh saat melakukan migrasi. Jarak tersebut kemudian dibedakan kedalam lima kategori, yaitu: tidak melakukan migrasi, migrasi dalam lingkungan penutur Bahasa jawa dengan dialek yang sama, migrasi ke lingkungan penutur bahsa jawa dengan dialek berbeda, migrasi ke lingkungan selain penutur bahasa Jawa di dalam negeri, migrasi ke luar negeri. Faktor multibahasa keluarga diukur berdasarkan jumlah yang digunakan oleh orang tua untuk berkomunikasi sehari-hari dengan anak.

Khusus untuk melakukan pengukuran terhadap variabel pergeseran penggunaan bahasa Jawa, peneliti menggunakan bantuan lima orang observer untuk mengamati bahasa yang digunakan oleh siswa TK dan KB untuk berkomunikasi sehari-hari. Masing masing observer menilai berdasarkan kriteria yang telah disajikan dalam lembar observasi. Data hasil pengukuran disajikan dalam subab berikut.

\section{Deskripsi Data}

Peneliti melakukan observasi dengan bantuan observer untuk mengukur pergeseran penggunaan bahasa Jawa pada siswa TK dan KB di Kelurahan Beduri Kecamatan Ponorogo Kabupaten Ponorogo. Sedangkan untuk variabel sekolah, status sosial ekonomi, migrasi, dan multibahasa keluarga peneliti menggunakan instrumen angket yang diisi oleh wali murid atau orang tua siswa TK dan KB di Kelurahan Beduri Kecamatan Ponorogo Kabupaten Ponorogo. Hasil pengukuran masing-masing variabel disajikan dalam diagram dibagian bawah halaman ini.

Data tiap variabel tersebut kemudian diuji persyaratan analisis regresi menggunakan bantuan program SPSS. Karena Path Analysis merupakan bentuk integrasi dari analisis regresi. Uji tersebut dilakukan agar tidak terjadi kesalahan pengukuran koefisien regresi yang dapat berakibat pada kurang tepatnya kesimpulan hasil penelitian.

\section{Uji persyaratan Analisis Regresi}

Uji persyaratan analisis regresi yang dilakukan dalam artikel ini meliputi uji normalitas, uji autokorelasi, Uji Multikolinieritas, dan uji heterokedastisitas. Formul yang digunakan untuk melakukan uji normalitas dalam artikel ini adalah kolmogorov Smirnov menggunakan bantuan program SPSS.

Hasil uji menunjukkan nilai Asym Sig untuk varibel multibahasa keluarga sebesar $0,074(>0,05)$, variable pergeseran penggunaan bahasa jawa $0,393(>0,05)$, variable sekolah $0,085(>0,05)$, variable status social ekonomi sebesar 0,274 $(>0,05)$, dan variabel

\section{Deskripsi Data}

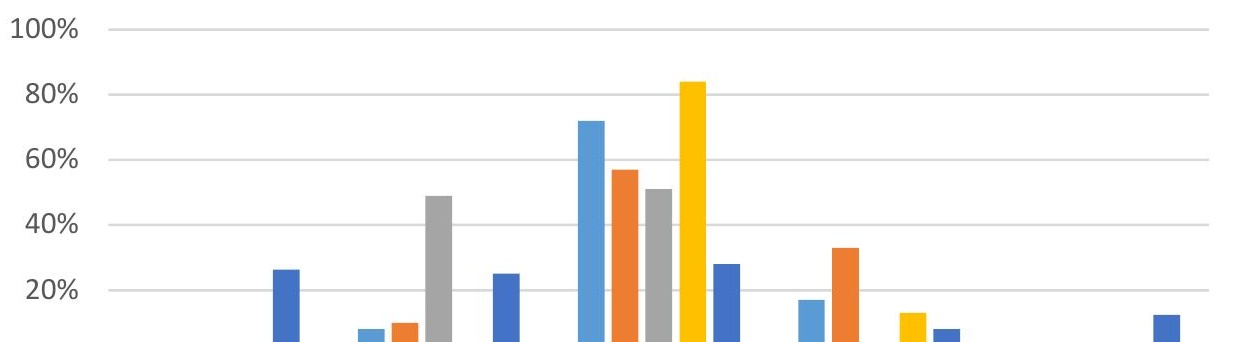


migrasi sebesar 0,084 (>0,05). Karena semua hasil analisis menunjukkan nilai lebih besar daripada 0,05 dapat disimpulkan bahwa semua data variabel dalam artikel ini berasal dari populasi yang berdistribusi normal.

Sesuai dengan jalur regresi yang dibangun dalam path analysis, uji autokorelasi, uji multikolinieritas, dan uji heterokedastisitas dilakukan dalam dua jalur pula. Jalur pertama menguji autokorelasi, multikolinieritas, dan heterokedastisitas variabel independen sekolah, status social ekonomi, migrasi, terhadap variabel dipenden multi bahasa keluarga. Jalur kedua menguji autokorelasi, multikolinieritas, dan heterokedastisitas variabel independen sekolah, status sosial ekonomi, migrasi, dan multi bahasa keluarga terhadap pergeseran penggunaan bahasa Jawa.

Hasil analisis menggunakan program SPSS jalur pertama menunjukkan nilai $\mathrm{d}_{\mathrm{L}}$ dan $\mathrm{d}_{\mathrm{U}}$ untuk taraf signifikan 0,05 dengan jumlah sampel (n) 61, dan jumlah variabel bebas (k) 3 , secara berurutan adalah 1,333 dan 1,272. Sedangkan nilai $\mathrm{DW}_{\text {hitung }}$ yang diperoleh sebesar 1,563. Hasil analisis untuk jalur ke dua, nilai $d_{L}$ dan $d_{U}$ untuk taraf signifikan 0,05 dengan jumlah sampel (n) 61, dan jumlah variabel bebas (k) 4, secara berurutan adalah 1,330 dan 1,457. Sedangkan nilai $\mathrm{DW}_{\text {hitung }}$ yang diperoleh sebesar 1,455. Kesimpulannya dalam jalur ini tidak terdapat autokorelasi.

Dalam uji multikolinieritas, hasil analisis dengan program SPSS untuk jalur pertama, diperoleh nilai koefisien korelasi variabel sekolah terhadap variabel status sosial ekonomi sebesar 0,020. Koefisien korelasi antara variabel sekolah dengan variabel migrasi sebesar 0,045. Koefisien korelasi variabel migrasi terhadap variabel multi bahasa keluarga sebesar 0,360. Koefisien korelasi antara variabel status sosial ekonomi dengan variabel migrasi sebesar 0,136. Koefisien korelasi antara variabel status sosial ekonomi terhadap variabel multi bhasa keluarga sebesar 0,069. Koefisien korelasi antara variabel migrasi terhadap pergeseran penggunaan bahasa sebesar 0,064. Seluruh koefisien korelasi antar variabel eksogen menunjukan angka kurang dari 0,90. Artinya seluruh variabel eksogen pada jalur pertama tidak terjadi multikolinieritas. Pengujian multikolinieritas jalur ke dua,hasil penghitungan dengan bantuan SPSS menunjukan nilai koefisien korelasi antara variabel sekolah dengan variabel status sosial ekonomi sebesar 0,005. Koefisien korelasi antara variabel sekolah dengan variabel migrasi sebesar 0,024 . Koefisien korelasi antara variabel status sosial ekonomi terhadap variabel sekolah sebesar 0,132. Semua koefisien korelasi antar variabel eksogen menunjukan angka di bawah 0,90. Artinya, tidak terdapat multikolinieritas pada variabel-variabel eksogen. Screeplot hasil analisis dengan bantuan program SPSS pada kedua jalur menunjukkan bahwa dalam jalur yang dirancang tidak terdapat heterokedastisitas. Dengan demikian seluruh variable dalam artikel ini layak untuk dianalisis menggunakan analisis regresi.

\section{Pengujian Koefisien Jalur}

\section{Jalur Pertama}

Pengujian untuk melihat pengaruh secara simultan antara faktor sekolah $\left(\mathrm{X}_{1}\right)$, SSE $\left(\mathrm{X}_{2}\right)$, migrasi $\left(\mathrm{X}_{3}\right)$, dan multi bahasa keluarga $\left(\mathrm{X}_{4}\right)$ terhadap pergeseran penggunaan bahasa Jawa oleh siswa TK dan KB di Kelurahan Beduri Kecamatan Ponorogo Kabupaten Ponorogo diperoleh koefisien determinasi, R Square sebesar 0,177. Pengujian kelayakan model regresi menunjukkan adanya hubungan linier yang signifikan antara sekolah, Status social Ekonomi, migrasi, multi bahasa keluarga terhadap pergeseran penggunaan bahasa Jawa dengn nilai sig 0,026.

\section{Jalur Kedua}

Pengujian untuk melihat pengaruh secara simultan faktor sekolah $\left(\mathrm{X}_{1}\right)$, SSE $\left(\mathrm{X}_{2}\right)$, dan migrasi $\left(\mathrm{X}_{3}\right)$, terhadap multi bahasa keluarga $\left(\mathrm{X}_{4}\right)$ siswa TK dan KB di kelurahan Beduri kecamatan Ponorogo kbupaten Ponorogo menunjukkan koefisien determinasi R Square sebesar 0,135. Uji kelayakan model, menunjukkan hasil bahwa terdapat hubungan linier yang signifikan antara sekolah, status sosial ekonomi, dan migrasi, terhadap multibahasa keluarga dengan nilai sig: 0,039. 


\section{Pengujian Parsial}

Pengujian parsial merujuk pada hasil perhitungan pengaruh masing-masing variabel independent terhadap variabel dependen. Berdasarkan perhitungan diperoleh hasil pada diagram jalur berikut:

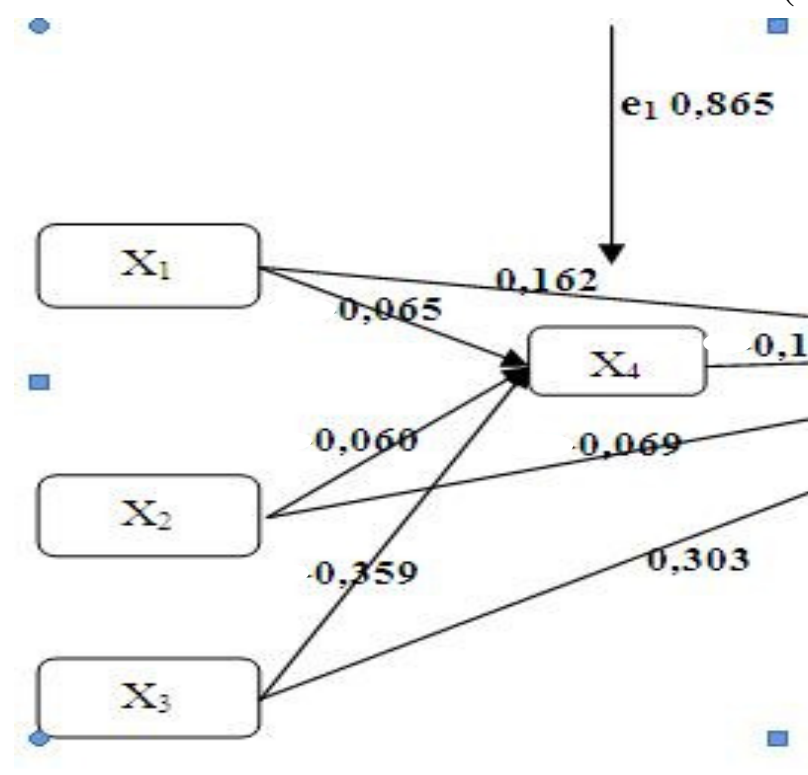

Secara parsial jalur pertama, pengaruh variabel sekolah (X1), status social ekonomi (X2), dan multibahasa keluarga (X4) terhadap pergeseran penggunaan bahasa Jawa (Y) tidak signifikan. Pengaruh yang signifikan ditunjukkan pada variabel migrasi (X3) terhadap pergeseran penggunaan bahasa Jawa (Y). Sedangkan pengujian parsial jalur kedua dengan variabel dipenden multibahasa keluarga (X4), variabel sekolah (X1) dan status social ekonomi (X2) tidak menunjukkan pengaruh yang signifikan. Pengaruh yang signifikanditunjukkan pada variabel atau faktor migrasi (X3). Diagram jalur tersebut memiliki persamaan struktural sebagai berikut.

Sub struktur $1: \mathrm{X}_{4}=0,065 \mathrm{X}_{1}+0,060 \mathrm{X}_{2}+$ $0,359 X_{3}+0,865$

Sub struktur 2: $\mathrm{X}_{5}=0,162 \mathrm{X}_{1}+0,135 \mathrm{X}_{4}+$ $0,069 \mathrm{X}_{2}+0,303 \mathrm{X}_{3}+0,823$

\section{Pengaruh Langsung}

Pengaruh langsung sekolah $\left(\mathrm{X}_{1}\right)$ terhadap pergeseran penggunaan bahasa (Y) sebesar 0,162. Semakin banyak bahasa yang digunakan di sekolah, maka pergeseran penggunaan bahasa Jawa yang terjadi pada siswa TK dan KB juga semakin besar atau semakin tidak menggunakan bahasa Jawa. Pengaruh langsung status sosial ekonomi $\left(\mathrm{X}_{2}\right)$ terhadap pergeseran penggunaan bahasa Jawa (Y) sebesar 0,069. Artinya jika status sosial ekonominya tinggi, pergeseran penggunaan bahasa Jawanya juga semakin besar. Pengaruh langsung migrasi $\left(\mathrm{X}_{3}\right)$ terhadap pergeseran penggunaan bahasa Jawa (Y) sebesar 0,303. Semakin kompleks pengalaman berbahasa seseorang melalui migrasi, maka penggunaan bahasa Jawanya juga lebih sedikit atau pergeserannya semakin besar. Pengaruh langsung multibahasa keluarga $\left(\mathrm{X}_{4}\right)$ Pergeseran penggunaan bahasa Jawa (Y) sebesar 0,135. Artinya jika semakin banyak bahasa yang digunakan di rumah, pergeseran pengunaan bahasa Jawanya juga semakin besar. Semua variabel eksogen memiliki pegaruh yang berarti terhadap variabel endogen.

\section{Pengaruh Tidak Langsung}

Untuk menghitung pengaruh tidak langsung (indirect effect), digunakan formula sebagai berikut:

1. Pengaruh variabel sekolah terhadap pergeseran penggunaan bahasa Jawa melalui multi bahasa keluarga: $P_{541}=\beta_{41} X \beta_{54}=$ $0,065 \times 0,135=0,008775$ 
2. Pengaruh variabel status sosial ekonomi terhadap pergeseran penggunaan bahasa Jawa melalui multi bahasa keluarga: $\mathrm{P}_{542}$ $=\beta_{42} \times \beta_{54}=0,060 \times 0,135=0,0081$

3. Pengaruh variabel migrasi terhadap pergeseran penggunaan bahasa Jawa melalui Multi bahasa keluarga: $P_{543}=\beta_{43}$ $X \beta_{54}=0,359 \times 0,135=0,048465$

Berdasarkan hasil penghitungan koefisien jalur (P) dapat diketahui bahwa pengaruh tidak langsung seluruh variabel eksogen yang dirancang dalam artikel tidak berarti terhadap pergeseran penggunaan bahasa Jawa. Artinya variabel sekolah, status sosial ekonomi keluarga, dan migrasi tidak memiliki pengaruh tidak langsung terhadap pergeseran penggunaan bahasa Jawa melalui multibahasa keluarga.

\section{Pengaruh Total}

Pengaruh total merupakan hasil penjumlahan dari pengaruh langsung dan pengaruh tidak langsung. Pengaruh total sekolah terhadap Pergeseran penggunaan bahasa Jawa $\left(\mathrm{P}_{\text {tot541 }}\right)$ 0,170775. Pengaruh total status social ekonomi keluarga terhadap pergeseran penggunaan Bahasa Jawa $\left(\mathrm{P}_{\text {tot52 }}\right)$ sebesar 0,0771. Pengaruh total migrasi terhadap pergeseran penggunaan Bahasa Jawa $\left(\mathrm{P}_{\text {tot53 }}\right)$ sebesar 0,35146. Semua pengaruh tersebut lebih besar dari 0,05 sehingga dinyatakan bahwa pengaruh tersebut berarti. Artinya semakin banyak bahasa yang digunakan sebagai bahasa pengantar di sekolah, semakin tinggi status sosial ekonomi keluarga, dan kompleks pengalaman migrasi keluarga, semakin besar pula pergeseran penggunaan bahasa Jawa yang dialami.

\section{PENUTUP}

Analisis jalur atau path analysis yang digunakan dalam penelitian, memungkinkan untuk mengetahui besar pengaruh langsung, pengaruh tidak langsung, dan pengaruh total dari variabel independen terhadap variabel dipenden yang dibangun dalam model. Sehingga diperoleh hasil yang lebih detil sebagai dasar untuk melakukan tindak lanjut.

Sesuai dengan tujuan penelitian, dapat disimpulkan bahwa (1) sekolah, status sosial ekonomi, migrasi, dan multibahasa keluarga memiliki pengaruh langsung yang signifikan terhadap pergeseran penggunaan bahasa Jawa, (2) tidak terdapat pengaruh tidak langsung yang signifikan dari sekolah, status sosial ekonomi, dan migrasi terhadap pergeseran penggunaan bahasa Jawa, (3) sekolah, status sosial ekonomi, dan migrasi memiliki pengaruh total yang signifikan terhadap pergeseran penggunaan bahasa Jawa.

Berdasarkan simpulan dari hasil artikel, disarankan: (1) stakeholder pendidikan anak usia dini diharapkan dapat membuat kebijakan tentang penggunaan bahasa Jawa sebagai bahasa pengantar di sekolah, (2) orang tua atau wali murid siswa TK dan KB diharapkan memaksimalkan penggunaan bahasa Jawa untuk berkomunikasi dengan anak, (3) peneliti berikutnya dapat melakukan penelitian tentang pergeseran penggunaan bahasa dengan variabel yang lain atau dengan metode penelitian yang berbeda.

\section{DAFTAR PUSTAKA}

Adawiyah, A., \& Munsi, M. F. "Character Values Represented in Tembang Sunda Cianjuran”. Indonesian Language Education and Literature, 5(1), 1.2019 https://doi.org/10.24235/ileal.v5i1.3590

Admodiwiro, Soebagio. Manajemen Pendidikan. PT Ardadizya, 2000.

Asmidayati dkk. Tokoh Filsafat Pendidikan Dr. Maria Montessori. UNY, 2011.

Chaer, Abdul. Tata Bahasa Praktis Bahasa Indonesia. Rineka Cipta, 2004. 
Fasolt. "Pengertian Pergeseran Bahasa." Repository USU, 2011, http://usu.ac.id/bitstream/.../4/Chapter 11.pdf.

Gould, W. T. S., and R.M. Prothero. Space and Time in African Population Mobility. Methuen, 1975.

Hakon, Leiulfsrud. Social Class in Europe. University of Trento, 2009.

Helen, Connor, and Sarah Dewson. . . Social Class and Higher Education: Issue Affecting Deciions on Participation by Lower Social Class Groups. Institute for Employment Studies, 2001.

Henry T., Fanny. "Kepunahan Bahasa-Bahasa Daerah.” Jurnal Masyarakat \& Budaya, vol. 11, no. 2, 2009, pp. 277-96.

Ibrahim dkk. "Faktor Sosial Yang Berpengaruh Terhadap Pergeseran Bahasa Lowa." KEMBARA: Jurnal Keilmuan Bahasa, Sastra Dan Pengajarannya, vol. 5, no. 2, 2019, pp. 208-18.

Kridalaksana, Harimurti. Wiwara: Pengantar Bahasa Dan Kebudayaan Jawa. Gramedia Pustaka Utama, 2001.

Macionis, J. Society: The Basics, and Meaning of Sociology, Package, 2ndEdition. Kenyon College, 1994.

Mardikantoro, Hari Bakti M., Hari. "Pergeseran Bahasa Jawa Dalam Ranah Keluarga Pada Masyarakat Multibahasa Di Wilayah Kabupaten Brebes." HUMANIORA, vol. 19, no. 1, 2007, pp. 43-51.

Muhammad, Fadilah. Desain Pembelajaran PAUD. Ar-Ruzz Media, 2012.

Mujid, and Suyanto. "Bahasa Jawa Di Provinsi Lampung Berdasar Data Sensus Penduduk 2010.” NUSA: Jurnal Ilmu Bahasa Dan Sastra, vol. 12, no. 1, 2017, pp. 15-26.

Nini, and Usman. "Pergeseran Bahasa Masyarakat Etnis Tionghoa Di Bima." MABASAN: Jurnal Ilmiah Bahasa Dan Sastra, vol. 13, no. 1, 2019, pp. 31-46.

Pedhazur, E. J. Multiple Regresion in Behavioral Research: Explanation and Prediction (3rded). Thomson Learning, 1997.

Pidarta, Made. Landasan Kependudukan. Rineka Cipta, 1997.

Pratiwi, Dwiyani. "Pergeseran Bahasa Sebagai Dampak Sikap Bahasa." DIKSI: Jurnal Ilmiah, Bahasa, Sastra, Dan Pengajarannya, vol. 13, no. 1, 2006, pp. 86-94.

Raihany, Afifah. "Pergeseran Bahasa Masyarakat Etnis Tionghoa Di Bima." NUANSA: Jurnal Artikel Ilmu Sosial Dan Keagamaan Islam, vol. 12, no. 1, 2015, pp. 29-57.

Sahril. "Pergeseran Bahasa Daerah Pada Anak-Anak Di Kuala Tanjung Sumatera Utara." RANAH: Jurnal Kajian Bahasa, vol. 7, no. 2, 2018, pp. 210-28.

Santrock, John W. Psikologi Pendidikan (Educational Psychology), Terj. Diana Angeica. Salemba Humanika, 2009.

Setyawan, Aan. "Bahasa Daerah Dalam Perspektif Kebudayaan Dan Sosiolinguistik." Proceedings International Seminar Language Maintenance and Shift, 2011, pp. 65-69.

Setyawan, Ilham. “Sikap Generasi 'Z' Terhadap Bahasa Jawa: Studi Kasus Pada Anak-Anak 
Usia Sekolah Dasar Di Kota Semarang." Jurnal Ilmiah Komunikasi Makna, vol. 7, no. 2, 2019, pp. 30-36.

Slavin, R. E. Educational Psychology:Theory and Practice (8thed). Pearson Education Inc., 2006.

Sumarsono, and Paina Partana. Sosiolinguistik. Pustaka Pelajar, 2002.

Syamsu L.N, Yusuf, and Nani M. Sugandhi. Perkembangan Peserta Didik. Raja Grafindo Persada, 2013.

Triyono, Sulis. "Pergeseraan Bahasa Daerah Akibat Kontak Bahasa Melalui Pembauran."

LITERA: Jurnal Artikel Bahasa, Sastra, Dan Pengajarannya, vol. 5, no. 1, 2006, pp. 12427.

Young, Elspeth. Aboriginal Employment: To What Purpose. ANPWS,ANU, 1985. 